\title{
表面にらせん溝を有する回転円板の摩擦抵抗低減*
}

\author{
渡 辺 敬 三*1, Budiarso*2 \\ 小方 聡*3, 上 村 圭 吾*4
}

\section{Drag Reduction of an Enclosed Rotating Disk with Fine Spiral Grooves}

\author{
Keizo WATANABE*5, Budiarso, \\ Satoshi OGATA and Keigo UEMURA \\ ${ }^{* 5}$ Tokyo University of Agriculture and Technology, Department of Technology and Risk Management, \\ 2-24-16 Naka-cho, Koganei-shi, Tokyo, 184-8588 Japan
}

\begin{abstract}
The purpose of this study is to obtain the new type of the drag reduction for the frictional moment of an enclosed rotating disk by using the fine spiral grooves on the disk surface. The experiments were carried out the measurement for the frictional moment of an enclosed rotating disk with fine spiral grooves, of which there were $120 \sim 160$ in the number and $0.1 \sim 0.2 \mathrm{~mm}$ in depth, respectively. The Reynolds number range is $4 \times 10^{4} \leq R e \leq 6 \times 10^{5}$. Test fluids are tap water and aqueous solutions of glycerin. It was seen that the drag reduction occurs in the turbulent flow range at the non-dimensional axial clearance $(s / a)=0.011,0.22$ and 0.33 , the maximum drag reduction ratio is approximately $15 \%$. The drag reduction depends on the number, the angle and the depth of the grooves. The fine spiral groove has the effect which suppresses the development of the fluctuation of transition region, and which delays the generation of the local turbulence in the transition range.
\end{abstract}

Key Words: Fluid Mechanics, Drag Reduction, Newtonian Fluids, Boundary Layer, Enclosed Rotating Disk, Frictional Moment, Flow Visualization, Velocity Profiles

\section{1. 緒論}

回転円板摩摖抵抗はポンプや水車などターボ機構の 羽根車の機械的損失動力に直接関連し, 羽根車の性能 向上とも密接にかかわるため, その評価は工学的・工 業的に重要である. 通常, その損失動力は容器内回転 円板摩擦抵抗の解析および実験結果から算定すること ができる。それゆえ，回転円板の摩擦抵抗やその低減 化の研究は従来から多く行われている.

流体の流動における抵抗は流体と固体壁の相互作用 により生じるとみなせば，その抵抗減少効果の応用は, 流体の特性を変える方法と固体表面の特性を変える方 法の二つに大きく分けることができる，従来報告され ている水溶性高分子(1) や界面活性剂(2)による容器内 回転円板の乱流摩擦抵抗低減効果は前者に分類され る.しかしながら, これら添加剤による方法は, 劣化

* 原稿受付 2005 年 3 月 18 日.

*1 正員, 東京農工大学大学院技術経営研究科( $184-8588$ 小 金井市叶町 2 24-16).

*2 University of Indonesia, Mechanical Engineering Dept. (Depok 16424 Indonesia).

*3 首都大学東察大学院工学研究科(画192-0397八王子肪南大 沢 1 1).

*4 東京都直大学大学院工学研究科(业192-0397八王子市南大 沢 1-1).

E mail : mot1z019(acc.tuat.ac.jp
の問題や環境への影響を考えると, 一般的なターボ機 械の運転状態では応用することが困難である、それゆ え, ターボ機械の羽根車への抵抗減少効果の応用は, 後者の固体表面の特性に着目した方法が適していると 考えられる.

このことに関連し, 著者らは壁面で流体の滑りを生 じさせる超はっ水性壁を固体表面に適用し, 容器内回 転円板摩擦抵抗に対する新しい抵抗減少効果を報告し た(3)(4). この方法は層流域での抵抗減少効果を得るこ とが可能であるが, ポンプ羽根車など高いせん断力が 長時間作用する流れ場では塗膜のはがれや摩耗などが 避けられず，その効果が失われるため，現時点でのこ れらの実用化は難しい。 それゆえ, 抵抗減少効果を有 する固体表面の実用化に際しては耐久性に優れた壁面 が必要となる.

この耐久性に優れた壁面の一つとしてリブレット(5) が考えられる.リブレットの回転円板への応用は, 耐 久性の点において優れていると考えられる. 渡部(6) は深さが 1〜 $6 \mathrm{~mm}$ の円周方向溝を回転円板および容 器壁面に付し, 摩擦抵抗の測定を行った. そして, 溝 の有無にかかわらず円板摩擦抵抗は無次元軸方向すき ま比 $(s / a)$ の影響を強く受け $(s / a)=0.0132$ 付近で最 小值を示すこと, 溝がある場合は無次元軸方向すきま 
比の影響は小さくなることを明らかにしている．しか しながら, それによる抵抗減少効果は得られていな い. 回転円板上の流れは三次元的な流れであり, 平板 上などのリブレットが適用できる流れ場と比較し乱流 への遷移状態が異なる。ゆえに、リブレットを回転円 板に適用し摩擦抵抗の低減化を得ることは難しいと考 えられる。

一方, Kármán(7)によって層流域および乱流域の回 転円板摩擦抵抗が解析されて以来, 多くの研究者によ ってその三次元境界層の特性が実験的に明らかにされ てきた. Gregory ら(8) は China-clayによる流れの可 視化などから円板上流れの遷移状態を詳細に明らかに した.さらに, 彼らは表面上に形成されるらせん渦の 本数およびその角度を実験的・解析的に明らかにして いる. 加藤ら ${ }^{(9)}$ は油膜法で得られた流跡から容器内 の回転円板の流れ角を測定し，流れ角は層流域では厳 密解にほぼ一致し, 乱流域ではレイノルズ数の増加と ともに減少することを報告した。

これらの研究結果をもとにして, 回転円板摩擦抵抗 の低減化を得る手法として, 可視化結果から得られた 円板近傍の流れに着目した.すなわち, 円板表面に流 れに沿うらせん状の溝を付すことで, 流れの制御を試 みる.よって, 本研究の目的は表面にらせん状の溝を 付加した回転円板を用いて, 容器内回転円板摩擦抵抗 における新しい抵抗減少効果を実験的に得ることであ る.さらに, 流れの可視化・速度分布測定を行い, そ のメカニズムを詳細に明らかにする。

\section{2. おもな記号}

$a$ : 円板半径 $\mathrm{mm}$

$C_{m}$ : 円板片面の摩擦モーメント係数 $=2 M / \rho \omega^{2} a^{5}$

$D R$ : 抵抗減少率 \%

$F^{*}$ : 無次元周波数 =周波数/円板回転周波数

$M$ : 円板片面に働く摩擦モーメント $\mathrm{N} ・ \mathrm{~m}$

$P:$ パワースペクトル

$R e$ :レイノルズ数 $=\omega a^{2} / \nu$

$R e_{L}$ : 局所レイノルズ数 $=\omega r^{2} / \nu$

$s$ : 軸方向すきま $\mathrm{mm}$

$u$ :円周方向速度成分 $\mathrm{m} / \mathrm{s}$

$v$ : 半径方向速度成分 $\mathrm{m} / \mathrm{s}$

$\phi:$ 流れ角

$\rho:$ 供試流体の密度 $\mathrm{kg} / \mathrm{m}^{3}$

$\nu$ : 供試流体の動粘度 $\mathrm{m}^{2} / \mathrm{s}$

$\omega:$ 円板角速度 $\mathrm{rad} / \mathrm{s}$

$r, \theta, z:$ 円筒座標

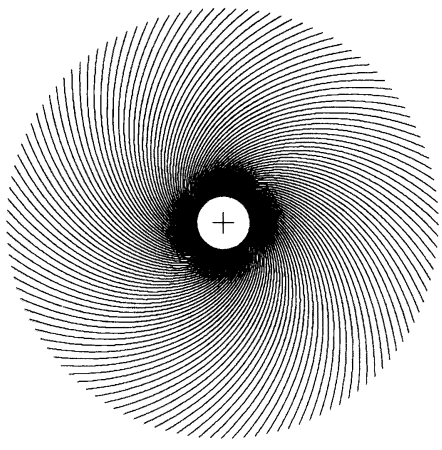

(a) Image of fine spiral grooves

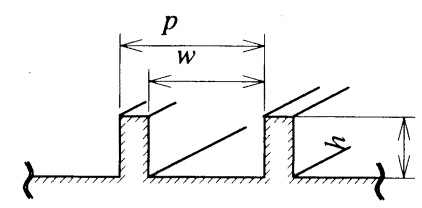

(b) Cross-sectional view of spiral grooves

Fig. 1 Fine spiral grooves on the disk

\section{3. 実験装置および実験方法}

$3 \cdot 1$ 供試回転円板本研究で用いた供試回転円 板は直径 $2 a=180 \mathrm{~mm}$, 厚さ $3 \mathrm{~mm}$ のアルミニウム製 で，その表面にはらせん溝が付してある。その作製は 円板表面をエッチングすることで行っている．図 1（a ）にらせん溝の原画の一例，（b ）に断面図を示す.

らせん溝の形状は従来の可視化結果をもとに, 以下 の対数らせん曲線に沿うものとした。

$$
r=r_{1} \exp \left(\frac{\pi}{180} \theta \cdot \tan \phi\right) \cdot
$$

ここで, $\phi\left(^{\circ}\right)$ は流れ角， $r_{1}$ は定数，rおよび $\theta$ は円 筒座標を表す。流れ角 $\phi$ は接線方向と半径方向のせ ん断応力の比である。

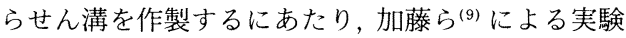
結果をもとにして流れ角 $\phi$ を局所レイノルズ数 $R e_{L}$. の関数として近似した。それは以下に示される。

$$
\phi=115-6.55 \ln R e_{L}
$$

式(2)を用いておのおのの半径位置での流れ角を算 出し, それを式 (1)に代入し対数らせん曲線を求め た.なお, 式中の定数は, 回転数 $1500 \mathrm{rpm}$ おび $20^{\circ} \mathrm{C}$ 水道水の物性値を用いた，また，流れ角が摩擦 抵抗に及ぼす影響を明らかにするため, 式 ( 2 )の流れ 角に加え, 流れ角を一定としたらせん溝も作製した。 それは, Cochran ${ }^{(10)}$ の層流域の厳密解である $\phi=$ $39.6^{\circ}$, 比較のための $\phi=25,45^{\circ}$ である.

表 1 にトルク測定実験で用いた供試回転円板の仕様 
Table 1 Test disk

\begin{tabular}{|c|c|c|c|}
\hline $\begin{array}{c}\text { Name of } \\
\text { disk }\end{array}$ & $\begin{array}{c}\text { Flow angle } \\
\phi\left(^{\circ}\right)\end{array}$ & $\begin{array}{c}\text { Number of } \\
\text { grooves } \\
n(-)\end{array}$ & $\begin{array}{l}\text { Hight of } \\
\text { grooves } \\
h(\mathrm{~mm})\end{array}$ \\
\hline e-120-01 & \multirow{10}{*}{ Eq. (2) } & \multirow{2}{*}{120} & 0.1 \\
\hline $\mathrm{e}-120-02$ & & & 0.2 \\
\hline e-14401 & & \multirow{2}{*}{144} & 0.1 \\
\hline $\mathrm{e}-144-02$ & & & 0.2 \\
\hline $\mathrm{e}-150-01$ & & \multirow[b]{2}{*}{150} & 0.1 \\
\hline $\mathrm{e}-150-02$ & & & 0.2 \\
\hline e-155-01 & & \multirow{2}{*}{155} & 0.1 \\
\hline e-155-02 & & & 0.2 \\
\hline $\mathrm{e}-160-01$ & & \multirow{2}{*}{160} & 0.1 \\
\hline e-160-02 & & & 0.2 \\
\hline $39-120-01$ & \multirow{2}{*}{39.6} & 120 & \multirow{6}{*}{0.1} \\
\hline $39-144-01$ & & 144 & \\
\hline $25-120-01$ & \multirow{2}{*}{25} & 120 & \\
\hline $25-144-01$ & & 144 & \\
\hline $45-120-01$ & \multirow{2}{*}{45} & 120 & \\
\hline $45-144-01$ & & 144 & \\
\hline
\end{tabular}

をまとめて示す。らせん溝本数 $n$ は Gregory ら ${ }^{(8)}$ の 可視化結果をもとに $n=120 \sim 160$ 本 $(r=90 \mathrm{~mm}$ の)位 置における溝幅 $w$ に換算すると $w=0.61 \sim 0.64$ $\mathrm{mm})$ とした。図 $1(\mathrm{~b})$ 中のらせん溝のピッチ $p$ は半 径位置 $r$ と溝本数 $n$ を用いて, $p=2 \pi r / n$ と表され る.また,らせん深さは $h=0.1,0.2 \mathrm{~mm} の 2$ 種類を 用意した。

一方, 速度分布および変動測定には, トルク測定実 験で抵抗減少効果を示した最適な溝 $(n=150$ 本, $h=$ $0.1 \mathrm{~mm})$ のらせん溝を付した直径 $2 a=400 \mathrm{~mm}$ の円 板を用意した。この場合, 溝幅 $w$ は円板外周位置 $(r$ $=200 \mathrm{~mm}$ の位置)で $w=73 \mathrm{~mm}$ である.

$3 \cdot 2$ 実験装置、ルク測定に用いた実験装置は 従来の研究(5) で用いたものと同一で，回転円板の片面 (らせん溝加工面）に作用するトルクのみが測定可能で ある. 実験は 5 種類の無次元軸方向すきま比 $[(s / a)=$ $0.011,0.033,0.11,0.22,0.33]$ に対して行った. 供試 流体は水道水およびグリセリン水溶液である.

流れの可視化にはアルミニウム粉法を用いた．可視 化実験は周辺を暗幕で覆い, $s=20 \mathrm{~mm}$ の場合は 0.2 $\mathrm{mg} / \mathrm{L}$ の割合でアルミニウム粉を懸濁させた水道水を 用い, 円板の側面からプロジェクタによるスリット光 $(0.5 \mathrm{~mm} \times 90 \mathrm{~mm})$ をスリット光の中心が円板表面か ら $0.25 \mathrm{~mm}$ の位置に当て, 正面から写真撮影をする ことで行った. $s=1 \mathrm{~mm}$ の場合は, 斜め $45^{\circ}$ の位置か ら光を当て正面から写真を撮った.

一方, 速度分布の測定は熱線流速計を用い行った。 固定壁側には熱線のトラバース装置の取付穴が, 無次 元半径位置, $(r / a)=0.425,0.5,0.575,0.65,0.725$, $0.8,0.875,0.95$ の各位置に設けてある。熱線は直径

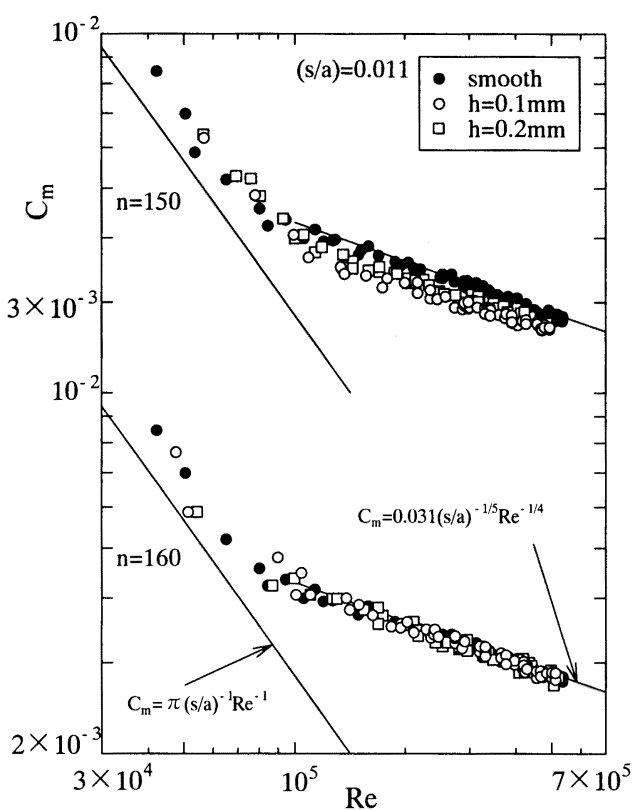

Fig. 2 Moment coefficient of disk with fine grooves at $(s / a)=0.011$

$4 \mu \mathrm{m}$ のタングステン線であり, プローブ形状は L 形 とした，供試流体は空気である，u方向および $v$ 方 向の速度分布は熱線をそれぞれの方向に向け測定する ことで行った，また，速度変動の測定は熱線流速計の データをオシロスコープで読取り FFT 解析すること で行った。熱線はつねに主流の方向(速度が最大とな る方向）に傾け, 主流方向のみの成分を検出した. FFT 演算のデー夕数は 4096 である.

\section{4. 実 験 結 果}

図 2 および図 3 に回転円板摩擦モーメント係数に対 する実験結果を $(s / a)=0.011$ および $(s / a)=0.22$ につ いてそれぞれ示す. 図 2,3 中の実線はそれぞれ層流 および乱流域のニュートン流体中の容器内滑面回転円 板の摩擦モーメント係数に対する半実験式(11) である. 図 2,3 は見やすいように溝本数ごとに上方にずらし てある。

図 2 に $(s / a)=0.011$ の場合(すきまが狭く回転円板 側境界層と固定壁側境界層が互いに干涉した流れ)の 実験結果を示す．滑面円板の摩擦モーメント係数は層 流・乱流域とも従来の結果とよく一致しており, 従来 の結果と同様に乱流への遷移は明確には生じない。一 方, $n=150$ 本のらせん溝を付した円板の場合, その摩 擦モーメント係数は $R e>10^{5}$ の領域で滑面円板より 小さい值を示し, 抵抗減少効果が生じていることがわ 


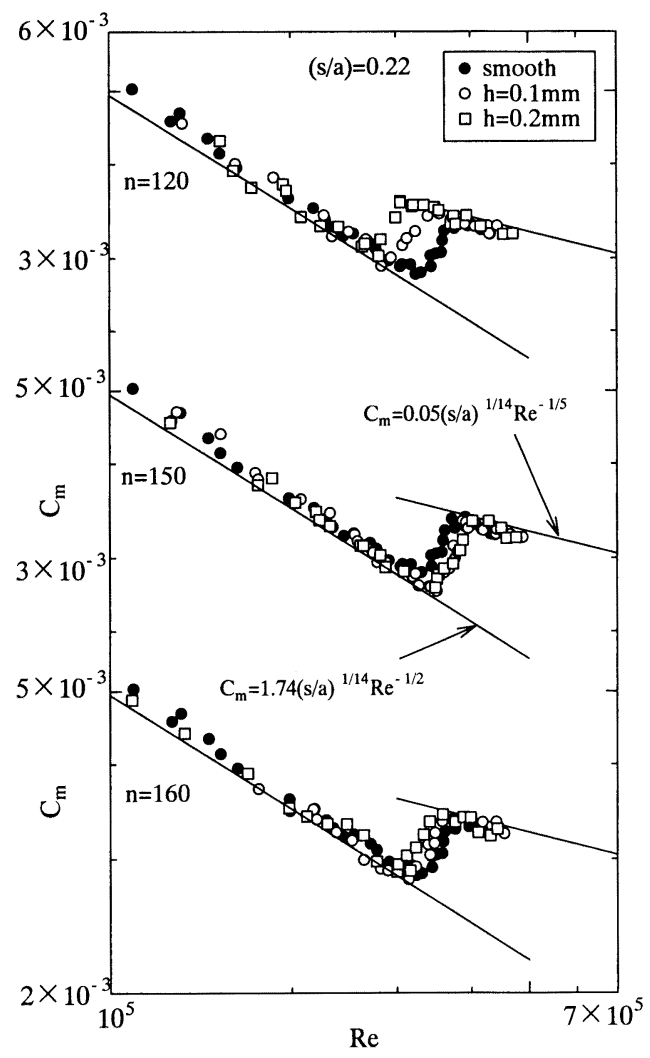

Fig. 3 Moment coefficient of disk with fine grooves at $(s / a)=0.22$

かるそその割合はレイノルズ数が増加するにつれ小さ くなる，また，溝深さが及ぼす影響はほとんど見られ ない. それに対し， $n=160$ 本の円板では層流域・乱 流域とも滑面円板との明確な違いは見られず, 抵抗減 少効果は生じないことがわかる.

図 3 に $(s / a)=0.22$ の場合(すきまが広く回転円板 側境界層と固定壁側境界層が干渉しない流れ)の実験 結果を示す．滑面円板の摩擦モーメント係数は従来の 結果と一致し, 乱流への遷移が $R e \cong 3 \times 10^{5}$ で生じる ことがわかる. 一方, らせん溝を有する回転円板の場 合はらせん溝の本数によりその遷移挙動が異なる. $n$ $=120$ 本では乱流への遷移が滑面と比較して早まり, その傾向は溝深さが深いものほど強くなる. らせん溝 の本数が多くなり $n=150$ 本になると溝深さによらず, 遷移が滑面に比べ遅れる。つまり，この領域で抵抗減 少効果が生じる.さらに溝の本数が増え $n=160$ 本に なると $n=120$ と同様, 遷移が早まる.

これらと同様の抵抗減少効果はすきまがより広い場 合である $(s / a)=0.33$ でも得られたが, すきまが狭い

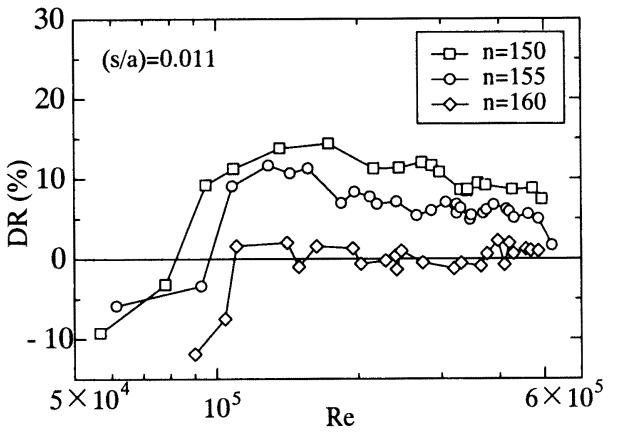

Fig. 4 Effect of Reynolds number on DR $[(s / a)=0.011]$

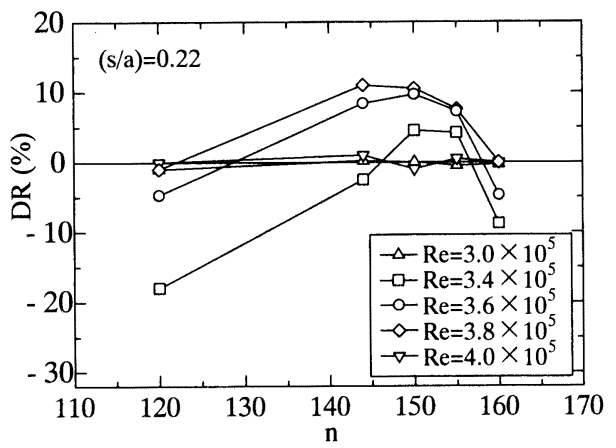

Fig. 5 Effect of number of grooves on DR $[(s / a)=0.22]$

$(s / a)=0.033,0.11$ ではこれらの効果が得られなかっ た.

次に，抵抗減少効果の大きさを定量的に見積もるた め, 以下の抵抗減少率 $D R$ で実験結果の整理を行う.

$$
D R=\left(C_{m s}-C_{m g}\right) / C_{m s} \times 100[\%]
$$

ここで, $C_{m s}$ は滑面円板, $C_{m g}$ はらせん溝を有する 回転円板の摩擦モーメント係数を表す.

図 4 に抵抗減少率とレイノルズ数の関係を $(s / a)=$ 0.011 の場合について示す。すきまが狭い場合には 8 $\times 10^{4}<R e<6 \times 10^{5}$ の領域で抵抗減少効果が生じるこ とがわかる。図 4 より明らかなように $R e \cong 10^{5}$ で約 $15 \%$ の抵抗減少を示した後, 徐々に抵抗減少が失われ る.一方，すきまが広い場合には， $3.4 \times 10^{5}<R e<$ $4.0 \times 10^{5}$ において, 最大約 $11 \%$ の抵抗減少を示した。

図 5 にらせん溝の本数 $n$ と抵抗減少率の関係を示 す. 図 5 より，抵抗減少効果はらせん溝の本数に依存 し極値をもち， $n=150$ 付近に抵抗減少を生じさせる 最適な溝本数が存在することがわかる.

また，流れ角の影響を明らかにするため，表 10 39-120-01〜45-144-01 の円板でも測定を行った結果, 流れ角が $\phi=25,39.6,45^{\circ}$ のらせん溝を有する円板で は, 乱流域の抵抗が滑面円板と比較し約 $10 \%$ 増加する 


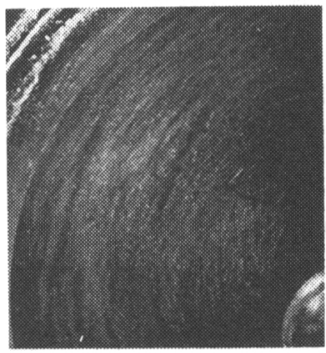

(a) Smooth disk

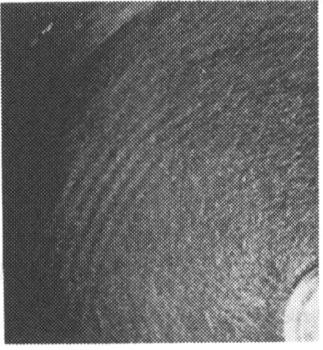

(b) Fine spiral grooves disk

Fig. 6 Flow pattern on the rotating disk for $s / a=0.011$

結果を得た。つまり，流れ角を一定としたらせん溝で は, らせん溝は粗さとなり逆に抵抗の増加を示す。

図 6 および図 7 に, $(s / a)=0.011$ で $R e=10^{5}$ の場合 および $(s / a)=0.22 て ゙ R e=2.5 \times 10^{5}$ の場合の流れの 可視化結果をそれぞれ示す。図 ( a ) は滑面円板, (b) はらせん溝の円板の結果をそれぞれ示している. 写真 はすべて回転円板の第 4 象限を撮影したものである。 円板は反時計回りに回転している。撮影条件はシャッ

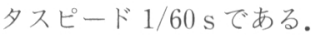

図6（a）から明らかなように，無次元軸方向すきま 比が狭い場合の滑面円板では従来の結果と同様, 円板 上にらせん状の局所乱れが生じていることがわかる。 この局所乱れの発生は循環流(二次流れ)の強さに起因 し，それは回転数の増加とともに広がり全面乱流へと 遷移する(12). 一方, 図 6(b)のらせん溝を有する円板 の場合, 円板表面にリング状模様が存在し，滑面円板 で観察された局所的な乱れがまだ発生していないこと がわかる。このリング状模様は滑面円板上流れの場合 は遷移域の不安定を示すものであり，同条件の滑面円 板では局所乱れの発生前の $R e_{L}=9 \times 10^{4}$ 付近で生じ る(12)。よって, 軸方向すきま比が小さい場合，らせん 溝は循環流に起因する局所乱れの発生を抑制するため に抵抗減少効果が生じたと考えられる。

図 7( a )の軸方向すきま比が広いときの滑面円板の 場合，周方向に対してやや傾いた白いすじが数本見ら れる。これらは回転円板上境界層の遷移域に見られる 流れの不安定性を示し遷移域に存在するらせん渦によ り生じる(13). 一方, 図 7(b)のらせん溝を有する円板 の場合，白いすじは滑面に比べて細く長くなることが わかる。よって，軸方向すきま比が大きい場合，らせ ん溝は遷移域の流れの横方向への広がりを抑制すると 考えられる。その結果, 遷移域が円板外周まで長く続 き，抵抗減少効果が生じたと考えられる。

図 8 に $(s / a)=0.22$ の場合の回転円板上速度分布を

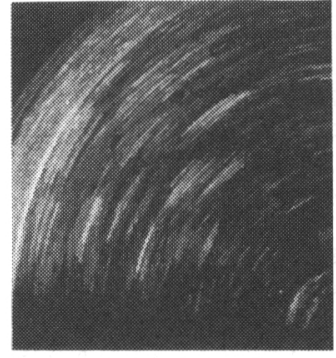

(a) Smooth disk

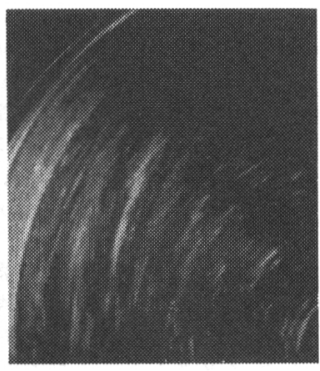

(b) Fine spiral grooves disk
Fig. 7 Flow pattern on the rotating disk for $s / a=0.22$

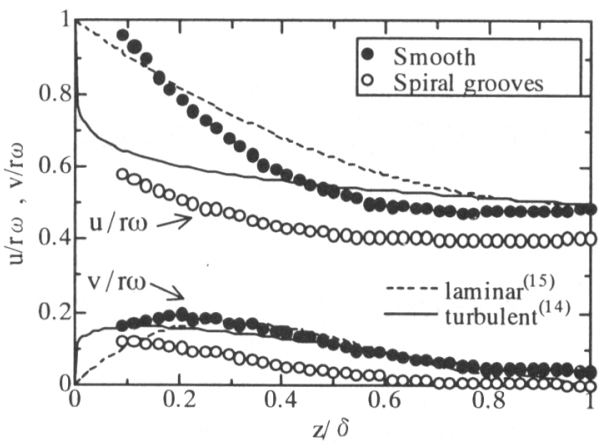

Fig. 8 Velocity profiles on the disk surface at $R e_{L}=$ $1.88 \times 10^{5}$

$R e_{L}=1.88 \times 10^{5}$ の場合について示す.図 8 中, 実線 は乱流 ${ }^{(14)}$, 破線は層流(15) の従来の滑面门板の実験式 を示している. 図 8 より, らせん溝を有する回転円板 の接線方向の速度 $u$ は滑面に比べ全体的に小さくな り乱流の速度分布に近くなることがわかった。一方, らせん溝を有する回転円板の半径方向の速度 $v$ はす ベての局所レイノルズ数で滑面に比べ小さくなり, 層 流の分布に近づく.このことは円板上の循環流(二次 流れ)が小さくなったことを意味し, 可視化の結果と 一致する.また, 局所レイノルズ数が大きくなり乱流 域になると, 速度分布の違いには明確な差は見られな くなり，らせん溝の効果はほとんどなくなった。一方, 回転円板摩擦モーメントは角運動量保存則から算出す ることができる. 周方向の速度分布 $u$ は滑面と比べ て乱流の速度分布に近づくが半径方向の速度が減少し たことにより, それらの運動量の積が滑面より小さく なることで, らせん溝による抵抗減少効果が生じたと 考えられる.

図 9 に $z / \delta=0.2$ に打ける主流速度変動の測定結果 を示す。滑面円板の場合, $R e_{L}=1.9 \times 10^{5}$ において規 則的な変動が生じ始め, $R e_{L}=2.1 \times 10^{5}$ で変動振幅が 


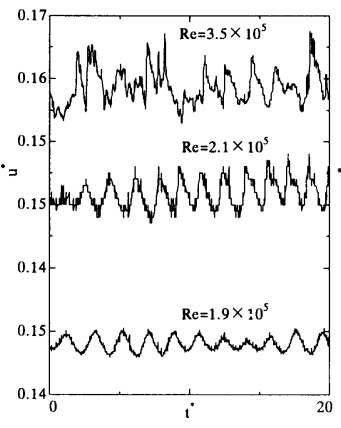

(a) Smooth disk

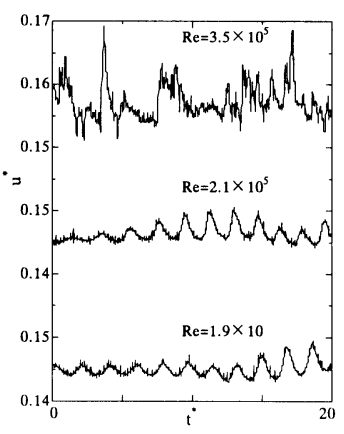

(b) Spiral grooves disk
Fig. 9 Velocity fluctuation at $z / \delta=0.2$

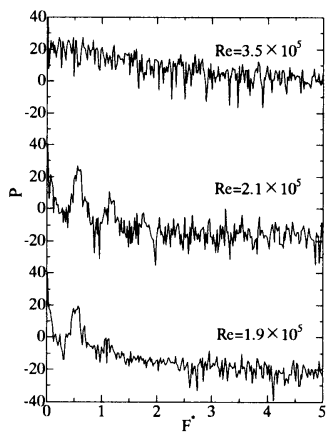

(a) Smooth disk

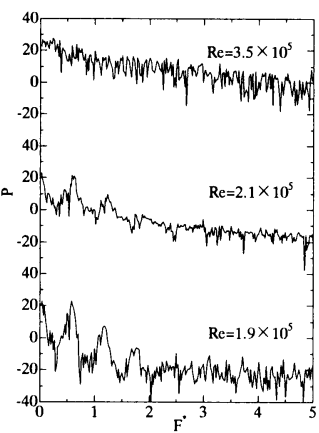

(b) Spiral grooves disk
Fig. 10 Power spectrum at $z / \delta=0.2$

増大する。これは回転円板上境界層の遷移領域におい て発生する不安定性によるものであると考えられ る(16).さらに回転数が増加し $\operatorname{Re}_{L}=3.5 \times 10^{5}$ になる と変動は乱雑化し乱流へと遷移する. 一方, らせん溝 を付加した円板では $\operatorname{Re}_{L}=2.1 \times 10^{5}$ においてのみ変 動振幅が減少しており, その前後の, $R e_{L}=1.9 \times 10^{5}$ および $\operatorname{Re}_{L}=3.5 \times 10^{5}$ では滑面との間に明確な違い は見られない.これらのことにより,らせん溝を有す る円板の遷移領域の変動は滑面と同様発生するが, そ の発達は抑制されることがわかる。この速度変動の発 達の抑制が二次流れを小さくしたものと考えられる。

図 10 に速度変動のパワースペクトルを示す，滑面 円板の場合, $R e_{L}=1.9 \times 10^{5}$ で現れた高周波成分は $R e_{L}=2.1 \times 10^{5}$ でそのパワーが増大し, $R e_{L}=3.5 \times$ $10^{5}$ で変動の乱雑化が進み乱流へと遷移していく(16).

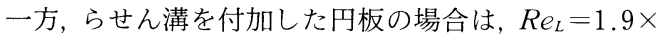
$10^{5}$ で低周波成分にパワーの増大が生じる. 局所レイ ノルズ数が増加し $\operatorname{Re}_{L}=2.1 \times 10^{5}$ になってもらせん 溝を付加した円板の高周波成分は滑面と異なり増大の 傾向を示さず，周波数成分もほとんど乱雑化しない.
$R e_{L}=3.5 \times 10^{5}$ では変動の乱雑化が進み滑面と同様乱 流へ遷移する.

前述したようにリブレットは粘性摩擦抵抗を減少さ せる効果をもつ。その形状により異なるが，リブレッ

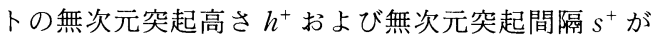
ある範囲にあるときに抵抗減少効果を示す(4). それら の無次元数で本実験を整理すると, $20<s^{+}<110,7<$ $h^{+}<35$ となる.これらの值は Walsh ら ${ }^{(4)}$ によるリブ レット効果の適用範囲より非常に大きい範囲である. しかしながら, V 字形リブレットでアスペクト比が小 さい場合 $s^{+}=200$ まで抵抗減少効果を示すという報 告もある(4). このことを考慮すれば, 本らせん溝の小 さいアスペクト比でもリブレット効果が適用できる可 能性もある. 現時点で, 従来のリブレット効果が本研 究の流れ場のように遠心力が作用する三次元的な流れ に適用できるかわからないが，これらの結果は一般的 なリブレットの効果のみで本抵抗減少効果は説明でき ないことを意味していると考えられる.

一方, 円板表面上の境界層はねじれており, 円板表 面からの高さによって主流の流れ角は変化する．前述 したように, 本研究では溝のらせん曲線を油膜厚さが 約 $50 \mu \mathrm{m}$ と考えられる加藤ら ${ }^{(9)}$ の油膜法の結果から 決定したが, 壁面からどの高さの流れに沿った方向に 切られた溝が最も効果的であるか現時点で不明であ る.リブレットと本研究結果の低減メカニズムとの対 比を含めて今後の研究課題といえる.

\section{5. 結 論}

回転円板摩擦抵抗の低減化を目的として，表面にら せん溝を付した回転円板の摩擦抵抗モーメント係数を 実験的に測定した.さらに, 流れの可視化および速度 分布・速度変動の測定を行った. 本研究の結論は以下 のようにまとめられる。

（1）すきまが狭い場合 $(s / a=0.011), の 10^{5}<R e$ $<6 \times 10^{5}$ 領域において，らせん溝を付した回転円板の 摩擦モーメント係数は滑面円板と比較し小さくなる。 そして, その領域に扔いて最大約 15\%の抵抗減少効果 を示す.

（2）すきまが広い場合 $(s / a \geq 0.22)$ ，らせん溝は 層流から乱流の遷移を遅らせる効果をもち, $3 \times 10^{5}<$ $R e<4 \times 10^{5}$ の領域で最大約 $11 \%$ の抵抗減少効果を有 する。

（3）らせん溝による抵抗減少効果は溝の角度, 本 数および深さに依存する.

（4）らせん溝は遷移領域の変動の発達を抑制する 効果を有するが, その発生段階にはほとんど影響を及 
ぼさない.この抑制効果のために層流域が広がり抵抗 減少効果が生じたと考えられる.

本研究は平成 16 年度科学研究費補助金・基礎研究 B ( 2 ) 15360099 の援助を受けたことを記し, 謝意を表 する。

\section{文献}

(1) Hoyt, J. W., The Effect of Additives on Fluid Friction, Trans. ASME, Ser., D(1972), 258-285.

（2）小方聡・渡辺敬三, 界面活性剤水溶液による回転円板摩 擦抵抗の低隇, 機論, 66-651, B (2000), 2899-2904.

（3）渡辺敬三・小方聡, 超はっ水性回転円板の二ュートン流 体における摩擦抵抗の低隇について，機論，63-612，B (1997), 2752-2756.

（4）小方聡・渡辺敬三, 容器内超はっ水性回転円板の摩擦抵 抗特性, 機論, 65-635, B (1999), 2391 2397.

(5) Walsh, J. M., Riblets as a Viscous Drag Reduction Technique, AIAA, J., 21-4 (1983), 485-486.

（6）渡部公明，回転円板の流体抵抗におよぼすすきまとみぞ の影響, 機論, 27-177 (1961), 583-593.

(7) Kármán, Th. Von, Über Laminare und Turbulente Reibung, Z. Angew: Math. Mech., 1 (1921), 233-252.

(8) Gregory, N., Stuart, J. T. and Walker, W. S., On the
Stability of Three-dimensional Boundary Layers with Application to the Flow due to a Rotating Disk, Philos. Trans. R. Soc. London, Ser A, 248 (1955), 155-199.

（9）加藤宏・渡辺敬三・納谷孝太郎, 高分子溶液中における 回転円板付近の流れについて, 機論, 44-379, B(1978), 970-978.

(10) Cochran W. G., The Flow due to a Rotating Disk, Proc. Camb. Philos. Soc., 30 (1934), 365-375.

（11）山田豊・伊藤基之, 容器内で回転する円すい体の摩擦抵 抗(第 1 報, 滑面円板の場合の摩擦モーメントと流れの観 察), 機論, 第 2 部, 41-341 (1975), 200-209.

（12）伊藤基之・山田豊・近藤直樹, 容器内回転円板まわりの 流れの可視化, 流れの可視化, 2-6 (1982), 523-528.

(13) Kohama, Y., Some Expectation on the Mechanism of Cross-Flow Instability in a Swept Wing Flow, Acta Mech., 66 (1987), 21-38.

(14) 黒川淳一・佐久間真人, 容器内回転円板にそう狭い隙間 ながれ, 機論, 53-492, B (1987), 2468-2476.

(15) Daily, J. W. and Nece, R.E., Chamber dimension effects on induced flow and frictional resistance of enclosed rotating disks. Trans. ASME, J. Basic Eng., 82 (1960), 217-232.

（16）伊藤基之・山田豊・西岡潔, 容器内回転円板まわりの流 れの不安定と遷移過程, 機論, 54-502，B (1987)，12361243. 